Martin Roland

Wiedeń

\title{
Sto lat katalogowania \\ średniowiecznych rękopisów iluminowanych w Wiedniu
}

\section{Tho historyczne i dzieje bibliotek}

W zakresie zbiorów historycznych w ogóle, a w szczególności rękopisów iluminowanych, Austriacka Biblioteka Narodowa (Österreichische Nationalbibliothek) należy do czołowych placówek tego typu na świecie. Doniosłość przechowywanych w jej magazynach skarbów pozostaje w rażącej dysproporcji w stosunku do $80,000 \mathrm{~km}^{2}$ powierzchni Republiki Austrii, w granicach ustanowionych przez traktat $z$ Saint Germain w $1919 \mathrm{r}$.

Po zakończeniu pierwszej wojny światowej mieszkańcy nowoutworzonej Republiki wcale nie uważali się za Austriaków, ani nie tworzyli jednej wspólnej kultury. Wręcz przeciwnie, postrzegali siebie $z$ jednej strony jako część kultury niemieckojęzycznej, $z$ drugiej zaś za Styryjczyków, Tyrolczyków, Karyntyjczyków itd. Każdy $z$ tych „krajów koronnych" mial silne korzenie autoidentyfikacji, sięgające wstecz do średniowiecza. Ponadto przyznawali się do ponadnarodowej wspólnoty, która skupiała się wokół tradycji monarchii habsburskiej, silnie związanej z Wiedniem, jako jej naczelną siedzibą.

Ta funkcja centrum dziedzicznego cesarstwa jest podstawa Austriackiej Biblioteki Narodowej i jej skarbów. Jako biblioteka wyrosła $z$ dworskich zbiorów książą austriackich, którymi od 1282 r. byli Habsburgowie, posiada zasoby sięgające XIV wieku. Pierwszym kamieniem milowym na drodze do obecnych zbiorów bylo panowanie Fryderyka III (1415-1493), który jako król niemiecki i cesarz połączył księgozbiory odziedziczone po swych luksemburskich poprzednikach na tronie niemieckim i rzymskim: Wacławie IV czeskim i Zygmuncie Luksemburskim. Dzięki temu w drugiej połowie XVI w. powstawała regularna biblioteka, $z$ bibliotekarzami i opracowywaniem zasobu.

Zbiory biblioteki książęcej ograniczają się do okazałych tomów (pod względem poziomu wykończenia artystycznego) oraz tematyki humanistycznej-prac odzwierciedlających zainteresowania filologiczne i historyczne. Dopiero w wieku XVIII biblioteka została wręcz zalana książkami z bibliotek klasztornych i innych, które wprowadziły pierwiastki encyklopedyzmu. Wiązało się to $z$ intelektualnymi tendencjami oświeceniowymi. Zmiany owe postawiły na porządku dnia 
problem naukowego opracowywania zbiorów, jako jednego $z$ najważniejszych zadań stojących przed personelem „Biblioteki Dworskiej” (Hofbibliothek).

\section{Naukowe podstawy prac i seria wickhoffowska}

Historia sztuki to młoda dyscyplina naukowa, która wyemancypowała się spośród „nauk pomocniczych historii” (historische Hilfswissenschaften) takich jak paleografia, sfragistyka itp., zaledwie w drugiej polowie XIX w. Dlatego te $\dot{z}$ dopiero w tym okresie możemy dopatrywać się naukowych prac bibliotecznych poświęconych szacie plastycznej książki (które koniecznie trzeba odróżnić od zainteresowań bibliofilskich).

Katalogowanie rękopisów iluminowanych nie wynikło jednak ze starań zainicjowanych w Hofbibliothek, lub w którejkolwiek innej bibliotece, lecz wyrosło $z$ badań historycznych podejmowanych w ufundowanym w $1854 \mathrm{r}$. Institut für Österreichische Geschichtsforschung ${ }^{1}$. Co więcej, opisywanie zabytków pochodzących $z$ różnych regionów, które prowadzono w założonej w 1850 r. K. K. Zentralkommission für die Erforschung und Erhaltung der Kunst- und historischen Denkmale $^{2}$, należy również uznać za niepozbawione konsekwencji, chociaż Wickhoff pomija je milczeniem.

W następstwie powyższych wysilków, seria zalożona przez Franza Wickhoffa (1853-1909), nie ograniczała się już do jednej biblioteki, lecz starała się syntetyzować badania nad rękopisami iluminowanymi, pochodzącymi $z$ wybranych krajów koronnych, należących do austriackiej części monarchii austrowęgierskiej. Wypracowano formalny schemat opisu, a seria zostala zatytułowana Beschreibendes Verzeichnis der illuminierten Handschriften in Österreich (Opisowy wykaz iluminowanych rękopisów w Austrii). I chociaż pierwszy tom tego wydawnictwa ukazal się dopiero w $1905 \mathrm{r}^{3}$, to jednak prace przygotowawcze podjęto już całą dekadę wcześniej.

W krótkiej przedmowie dołączonej do pierwszego tomu Wickhoff podkreślil wyjątkową wagę systematycznego zbierania informacji na temat źródeł z punktu widzenia wszystkich połączonych dyscyplin (historycznych). Swą nową serię przedstawil w ten sposób jako wkład w rozwój historii sztuki jako dziedziny nauki opartej na ścislej metodologii.

\footnotetext{
${ }^{1}$ Nazwa tej instytucji zmieniala się kilkakrotnie; podana wyżej była w użyciu do 1923 r., a następnie od 1945 do dziś. W latach 1923-1942 Instytut nosil miano: Österreichisches Institut für Geschichtsforschung, a od 1942 do 1945: Institut für Geschichtsforschung und Archivwissenschaften.

${ }^{2}$ Nazwa ta obowiązywała od 1873 do 1910 r. Wcześniej (1850-1873) komisja występowała jako Central-Commission zur Erforschung und Erhaltung der Baudenkmale.

${ }^{3}$ Hermann Julius Hermann, Die illuminierten Handschriften in Tirol. „Beschreibendes Verzeichnis der illuminierten Handschriften in Österreich", 1, ed. Franz Wickhoff, Leipzig 1905 (dalej cyt.: Hermann, Tirol). Pełne zestawienie bibliograficzne wszystkich katalogów rękopisów iluminowanych dostępne na: http://paecht-archiv.univie.ac.at/dateien/
} 
Podobnie jak w dyscyplinach historycznych, gdzie konieczne jest systematyczne, kolektywne publikowanie źródeł, możliwie pełne udostępnianie materiałów dla różnych galęzi historii sztuki równiė przyczyni się do rozwoju tej dziedziny nauki ${ }^{4}$.

Następnie Wickhoff uzasadniał dlaczego nowe „wydanie” źródel jest konieczne: przede wszystkim $z$ tego powodu, że wiele bibliotek znajduje się w odleglych miejscach, gdzie trudno dotrzeć. Niemniej - kontynuował uczony - nawet wielkie biblioteki, jak dotąd nie poradzily sobie $z$ właczeniem informacji o zdobnictwie rękopisów do swych katalogów. I dlatego ta nowa seria ma ważną rolę do wypelnienia.

Gdy Wickhoff pisał ową przedmowę, w obiegu naukowym funkcjonowaly już obszerne, przelomowe prace takie jak na przykład jego wlasne studia nad Genesis wiedeńską (1895) ${ }^{5}$, lub opublikowany w 1893 r. fundamentalny artykuł na temat rękopisów króla Wacława, pióra jego ucznia Juliusa von Schlossera ${ }^{6}$. Wickhoff byl w pelni świadom, że badania tego rodzaju i zainicjowane przez niego katalogowanie rękopisów iluminowanych to dwie zupełnie różne sprawy. Dlatego też zastrzegl:

Podjęte wysilki ... nie mają na celu wyczerpującej naukowej analizy przedstawianych materiałów, lecz dążą do zwięzłego zapoznania specjalistów $z$ dostępnymi źródłami

Po opublikowaniu przygotowanego przez Hermanna Juliusa Hermanna tomu poświęconego rękopisom $\mathrm{z}$ Tyrolu (1905), w tym samym roku ukazal się drugi, prezentujący kodeksy salzburskie ${ }^{8}$. Ksiazżke tę, podobnie jak tom zajmujący się materialami $z$ Karyntii ${ }^{9}$, zapowiedzial Wickhoff $\mathrm{w}$ cytowanej wyżej przedmowie. Inaczej było jednak $z$ czwartym woluminem przedstawiającym rękopisy czeskie, który według Wickhoffa byl już w przeważaącej mierze gotowy. Ten tom nie ukazal się nigdy. Wickhoff odniósł się także do „przebogatych za-

${ }^{4}$ Hermann, Tirol, s.: „Wie es in den historischen Wissenschaften notwendig ist, das Material an Quellen systematisch und gesammelt zu veröffentlichen, so wird es auch auf die Behandlung der Kunstgeschichte fördernd einwirken, wenn das Material für einzelne $Z$ weige so viel als möglich vollständig bekannt gemacht wird."

${ }^{5}$ Wilhelm von Hartel, Franz Wickhoff, Die Wiener Genesis, Beilage zu: „Jahrbuch der kunsthistorischen Sammlungen des Allerhöchsten Kaiserhauses", Wien 1893 i 1895 (reprint: Graz 1970).

${ }^{6}$ Julius von Schlosser, Bilderhandschriften Königs Wenzel I, ,Jahrbuch der kunsthistorischen Sammlungen des Allerhöchsten Kaiserhauses", 14:1893, s. 214-317 (kilka reprintów).

${ }^{7}$ Hermann, Tirol (por. przyp. 3), s. VII: „Die vorliegende Arbeit ... hat nicht den Zweck, das Material wissenschaftlich zu erschöpfen, sondern sie soll in ihrer knappen Fassung die Fachgenossen mit dem Material bekannt machen."

${ }^{8}$ Hans Tietze, Die illuminierten Handschriften in Salzburg, „Beschreibendes Verzeichnis der illuminierten Handschriften in Österreich", 2, ed. Franz Wickhoff, Leipzig 1905.

${ }^{9}$ Robert Eisler, Die illuminierten Handschriften in Kärnten, „Beschreibendes Verzeichnis der illuminierten Handschriften in Österreich", 3, ed. Franz Wickhoff, Leipzig 1907. 
sobów Najjaśniejszego Dworu Cesarskiego”, które uznal za „w większej części rozpoznane"10. Opinię tę - jako ze zespół Biblioteki Narodowej jeszcze po stu latach nadal dokłada wysiłków, by zakończyć katalogowanie - należy uznać za cokolwiek optymistyczną. Z drugiej jednak strony, szybkie publikowanie kolejnych tomów serii po pierwszej wojnie światowej dobitnie zaświadcza o postępie badań dokonanych przez Hermanna Juliusa Hermanna (inicjatora i animatora prac przy drugiej serii), który od początku sprawowal pieczę nad zbiorami wiedeńskimi.

Do 1917 r. ukazało się siedem tomów, obejmujących 1342 rękopisy - ich opisy zajmują przeszło 1300 stron, którym towarzyszy przeszło tysiąc ilustracji ${ }^{11}$.

Jednak nawet najwspanialej wyglądające liczby nie gwarantują zaawansowania w zakresie metodologii i pomysłów badawczych ${ }^{12}$. Zasadniczej wskazówki, która wyjaśnia naukowe znaczenie serii, dostarcza jej tytuł Beschreibendes Verzeichnis, czyli „opisowy wykaz”. Słowo wykaz odnosi się tu do przejrzyście skonstruowanego schematu, który umożliwia czytelnikowi odnajdywanie pożądanych informacji w spójnym wewnętrznie następstwie ${ }^{13}$. Opis jednostki zaczyna się od kolejnego numeru wewnątrz danego tomu, by następnie przejść do sygnatury bibliotecznej, tytułu ogólnego określającego zawartość, informacji kodykologicznych, charakterystyki pisma, skrótowego przedstawienia zdobnictwa, i na koniec opisu oprawy tomu. Kolejny akapit zawiera lokalizację rekopisu, jego datowanie i dalsze szczegóły dotyczące pisarza, iluminatora i proweniencji (jeżeli są znane). Następna część jest opisowa i wylicza elementy zdobnictwa od początku księgi do jej końca, często podając informacje na temat treści rękopisu, jeżeli wiązę się ona ze zdobnictwem, lub odgrywa rolę ze względu na klasyfikację kodeksu.

„Tylko pojedyncze, szczególnie ważne rękopisy, są opisane w sposób bardziej szczegółowy"14. To ostatnie zdanie Hermanna jest nieprecyzyjne: nie oznacza, że opis wybranych rękopisów jest bardziej szczegółowy, lecz odnosi się do pojedynczego punktu, w którym Hermann poszerza aparat naukowy dokumentujący jego klasyfikację.

Tom poświęcony Tyrolowi zawiera charakterystykę zbiorów różnych instytucji, które, ze względu na fakt iż są bardzo różnej wielkości, zostały uporządkowane według sygnatur bibliotecznych. Uporządkowanie tego rodzaju powoduje, ze książka traci wewnętrzną spójność - trudno śledzić rękopisy zarówno wedlug klucza pochodzenia, jak $\mathrm{i}$ daty powstania. $\mathrm{W}$ tomie czwartym, poświęconym potężnym kolekcjom dwóch bibliotek klasztornych ze Styrii, niedomagania te

${ }^{10}$ Hermann, Tirol, s. VII.

${ }_{11}$ Pehne dane bibliograficzne na: http://paecht-archiv.univie.ac.at/dateien/

${ }^{12}$ Przed tym samym problemem stoimy $w$ dniu dzisiejszym, gdy podejmowany jest problem oceny projektów digitalizacji źródeł historycznych. Jestem przekonany, że olbrzymie ilości zdigitalizowanych stron rękopisów jeszcze nie przesądzają faktu, że za danym projektem stoi przekonująca koncepcja.

${ }^{13}$ Hermann, Tirol, s. IX-X.

${ }^{14}$ Hermann, Tirol, s. X: „Nur einige besonders hervorragende Codices sind etwas ausführlicher beschrieben." 
zostały wyeliminowane ${ }^{15}$. Autor tego woluminu, Paul Buberl, argumentował, że związi pomiędzy rekopisami a skryptoriami uległyby zatarciu, gdyby materiały ułożono według formatów ksiąg (zwykle stosowane kryterium w przypadku nadawania sygnatur). Wprowadził więc uporządkowanie wedlug lokalnych szkól, a wewnątrz tak wyodrębnionych grup zastosował kolejność chronologiczną i stylistyczną. Czy to ważne osiągnięcie metodyczne zostalo zaakceptowane przez Wickhoffa (który zmarł w 1907 r.), Buberl już nie wspomina.

Schemat opisu, wypracowany w pierwszych tomach serii Wickhoffa, stal się najbardziej wpływowym punktem odniesienia dla innych instytucji, które podejmowały się publikacji katalogów rękopisów iluminowanych. Katalogi zbio-

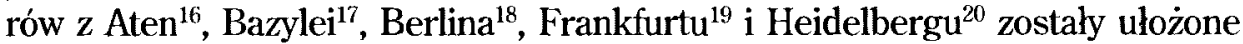
w bardzo podobny sposób. Późnym, choć ważkim pokłosiem tego schematu jest także opublikowany w 1958 r. katalog Zofii Ameisenowej ${ }^{21}$.

Jednak, czy pomyst publikowania katalogów rękopisów iluminowanych byl rzeczywiście nowością? Wickhoff nie wspomina o jakichkolwiek dawniejszych wydawnictwach, które by uznawał za inspirację. I chociaż przywołanie wcześniejszych, ważnych przykładów jest możliwe ${ }^{22}$, mimo to klarowna struktura opisów wiedeńskich nie znajduje oczywistych antecedensów.

15 Paul Buberl, Die illuminierten Handschriften in Steiermark 1: Die Stiftsbibliotheken zu Admont und Vorau, „Beschreibendes Verzeichnis der illuminierten Handschriften in Österreich”, 4/1, ed. Max Dvolák, Leipzig 1911.

${ }^{16}$ Paul Buberl, Die Miniaturenhandschriften in Athen, „Kaiserliche Akademie der Wissenschaften in Wien, Phil-hist. Klasse. Denkschriften”. 60, Wien 1917. Buberl należal do zespołu „Beschreibendes Verzeichnis"(por. przyp. 15).

${ }^{17}$ Konrad Escher, Die Miniaturen in den Baseler Bibliotheken, Museen und Archiven, Basel 1917. Escher powołuje się bezpośrednio na wzorce wiedeńskie (s. IX).

${ }_{18}$ Joachim Kirchner, Beschreibendes Verzeichnis der Miniaturen und des Initialschmucks in den Phillipps-Handschriften, „Beschreibende Verzeichnisse der Miniaturen-Handschriften der Preußischen Staatsbibliothek zu Berlin", 1, Leipzig 1926. Bezpośrednie nawiazanie odnajdujemy w tytule; poza tym autor wspomina o wzorowaniu sie na modelu austriackim w przedmowie. Dalsze katalogi powielały ten sam wzór.

${ }^{19}$ Rosy Schilling, Die illuminierten Handschriften und Einzelminiaturen des Mittelalters und der Renaissance in Frankfurter Besitz, Frankfurt/Main 1929. Powołanie przykładu wiedeńskiego znajdujemy na s. XIII; mimo wzorowania się, Schilling w znaczący sposób ulepszyla zastany schemat.

${ }^{20}$ Hans Wegener, Beschreibendes Verzeichnis der deutschen Bilder-Handschriften des späten Mittelalters in der Heidelberger Universitäts-Bibliothek, Leipzig 1927. Wegener wyjaśnia, że starsze rękopisy zostaly już wcześniej opisane przez A(dolfa) von Oechelhaeusera (Die Miniaturen der Universitäts-Bibliothek zu Heidelberg, 1. Heidelberg 1887). Niemniej, przeglądając to wydawnictwo nie sposób nie zauważyc, że sklada się ono $z$ tekstu narracyjnego, który niewiele ma wspólnego z nowoczesnymi wykazami typu wiedeńskiego.

${ }^{21}$ Zofia Ameisenowa, Rękopisy i pierwodruki iluminowane Biblioteki Jagiellońskiej, Wrocław - Kraków 1958.

${ }^{22}$ Ważną rolę odegrała praca, którą wydał Éduard Fleury, Les manuscrits miniatures de la bibliothèque de Laon (...), t. 1-2, Laon 1863. Publikacja ta stanowi przykład pierwszych prób podejścia historyka sztuki do katalogowania rękopisów iluminowanych. Jeszcze wcześniej wydana została książka Achille Durieux, Les miniatures des manuscrits de la bibliothèque de Cambrai avec catalogue des Volumes Vignettes et un Album de dix-huit Planches in $4^{\circ}$, contenant plus de cent Dessins (au trait fac-simile), Cambrai 1861, do której odnosi się Fleury. Do pracy tej jednak nie udało mi się dotrzeć. 


\section{"Cud" w Wiedniu - ponowny start serii}

\section{pod kierownictwem Hermanna Juliusa Hermanna}

W przedmowie do wydanego w 1905 r. pierwszego tomu jego serii, Franz Wickhoff optymistycznie stwierdzil, że sporo materiałów zostało już zebrane, w tym bogate zbiory wiedeńskiej biblioteki dworskiej (Hofbibliothek), i że wkrótce zostaną one opublikowane. Tymczasem rozpad monarchii habsburskiej i utworzenie republiki, $z$ którą nikt się nie identyfikował, stworzyły najdogodniejsze warunki, by tak kojarzący się $z$ cesarstwem projekt nie został nigdy zrealizowany.

Jednakże - i trzeba przyznać, ze dokonanie to należy do najbardziej zadziwiających - Julius Schlosser i Hermann Julius Hermann zainicjowali publikowanie podserii zatytułowanej Die illuminierten Handschriften und Inkunabeln der Nationalbibliothek in Wien (Iluminowane rękopisy i inkunabuly Biblioteki Narodowej w Wiedniu), która skupiła swą uwage na zasobach bylej Hofbibliothek.

W kontekście początków nowej serii należy zwrócić uwagę na dwa aspekty. Po pierwsze nazwa biblioteki, której zabytki wzięto pod lupę, uległa zmianie, a co więcej, nowa nazwa tej „narodowej” instytucji celowo omijała określenie narodu. Po wtóre, nowe wydawnictwo od początku zakładało objęcie badaniami także inkunabułów. Zwłaszcza ten drugi aspekt miał przełomowe znaczenie dla przyszłości, ponieważ podkreślal integralność dyscypliny określanej po niemiecku jako „Buchwesen” (nauka o ksiażce) - terminem, który jest dosyć trudny do precyzyjnego przetlumaczenia na inne języki ${ }^{3}$. Instytucje, które przyjęły odpowiedzialność za publikowanie kolejnych tomów nowej serii, to Österreichische Institut für Geschichtsforschung (por. przyp. 1) we współpracy z Kunsthistorische Institut der Universität Wien.

Ponieważ koncepcja wydawnictwa nie budziła wątpliwości, wielotomowe przedsięwzięcie mogło się rozpocząć w 1923 r., woluminem obejmującym chronologicznie najstarsze rękopisy zachodnie, pochodzące $z$ późnej starożytności i wczesnego średniowiecza ${ }^{24}$. W krótkich odstępach czasu Hermann Julius Hermann, który kierowal zespołem opisującym iluminowane rękopisy w Bibliotece Narodowej od samego początku przedsięwzięcia, zdołał opublikować szereg tomów. Owa ciagglość kierownictwa wyjaśnia też sekret względnie szybkiego opublikowania tylu części: trzynaście spośród piętnastu wydanych wówczas tomów to dzieło życia Hermanna Juliusa Hermanna; dwa pozostałe tomy, to rezultat wysilków Paula Buberla, który w 1930 r. podjąl prace nad opisywaniem dziedzictwa bizantyńskiego. Jego dokonania są bardzo ciekawe $z$ punktu widzenia metodyki, ponieważ pierwszy z nich koncentruje się całkowicie na dwóch

23 „Kommission für Schrift- und Buchwesen des Mittelalters” (por. wyżej, s. 13) posługuje się następującym angielskim przekładem swej nazwy: „Commission of Paleography and Codicology of Medieval Manuscripts in Austria".

${ }^{24}$ Hermann Julius Hermann, Die frïhmittelalterlichen Handschriften des Abendlandes, „Beschreibendes Verzeichnis der illuminierten Handschriften in Österreich", 8, ed. Julius Schlosser, Hermann Julius Hermann = Neue Folge: Die illuminierten Handschriften und Inkunabeln der Nationalbibliothek in Wien I), Leipzig 1923. 
zabytkach: Dioskurydesie oraz Genesis wiedeńskiej (1937) - tym samym Buberl zakwestionował ideę ograniczenia się do zwięzłego katalogowania zasobów; drugi z przygotowanych przez niego tomów prezentuje 111 rękopisów, datowanych od X po XVIII wiek (1938).

Między 1923 a 1938 r. wydano w sumie piętnaście tomów, które objęły prawie półtora tysiąca rękopisów, skatalogowanych na 3400 stronach tekstu; dołączony materiał poglądowy zawierał przeszło 1250 ilustracji. W porównaniu $z$ pierwszą serią nastąpiły istotne zmiany. Przede wszystkim przeciętna objętość tekstu poświęcona pojedynczemu rękopisowi wzrosła $z$ poniżej jednej strony do przeszło dwóch. Statystyczna ilość ilustracji przypadających na jeden rękopis pozostała podobna; zmienil się jednak ich rodzaj. Od czwatego tomu nie włączano juz materiałów ilustracyjnych do tekstu, lecz dołączano je w postaci przepięknych tablic wykonywanych głównie techniką światłodruku (była to zresztą cecha charakterystyczna serii od samego początku). Owe tablice najczęściej prezentują pojedynczą stronę rękopisu, jakkolwiek niekiedy dzielone były na części zawierające do sześciu detali. W efekcie utrzymana jest średnia 1,5 ilustracji na jeden rękopis.

W zakresie metodyki opisu nie odnotowujemy zmian. Podsumowując całość dokonania podkreślić należy, że opisano wszystkie rękopisy bizantyńskie, wszystkie romańskie rękopisy lacińskie, a ponadto wszystkie późniejsze rękopisy oraz inkunabuły włoskie. Co się tyczy rękopisów zachodnioeuropejskich, włączono w zakres opisywania wszystkie materiały do około $1400 \mathrm{roku}^{25}$. Ostatni z omawianych tomów opublikowany w 1938 r., a więc w czasie gdy Republika Austrii została (przymusowo) złączona $z$ nazistowskimi Niemcami, obejmuje materiały francuskie i pochodzące $z$ Półwyspu Iberyjskiego, powstałe w pierwszej połowie XVw. Hermann Julius Hermann nie miał ochoty współpracować $z$ nowym reżimem; w efekcie dalsze publikowanie serii zostało zawieszone.

\section{Trudne wznowienie prac po drugiej wojnie światowej}

Chociaż Austria wyszła $z$ drugiej wojny światowej zrujnowana, to jednak, co zadziwia w najwyższym stopniu, poddanie nazistowskiemu rez̈imowi wyksztalciło wśród polityków wszystkich orientacji i większości społeczeństwa, austriackie poczucie tożsamości narodowej. Ta zasadnicza zmiana w stosunku do Pierwszej Republiki umożliwiła odbudowę państwowości, a po dziesięciu trudnych latach wycofanie sił alianckich i ustanowienie neutralnej republiki w $1955 \mathrm{r}$. Nowe poczucie narodowej tożsamości znalazło wyraz w licznych aspektach kulturalnych, niemniej katalogowanie rękopisów iluminowanych nie należało do punktów, wokół których skupiała się uwaga narodu. Ani historycy sztuki, ani instytucje kultury nie poczuwały się do kontynuacji wydawnictwa Beschreibendes Verzeichnis.

${ }^{25}$ Tytuł serii zachodniej (t. 7: Die westeuropäischen Handschriften und Inkunabeln der Gotik und Renaissance mit Ausnahme der niederländischen Handschriften) wyklucza materiały niderlandzkie. Jak można się przekonać z lektury serii Pächta, zaledwie dwa przykłady rodem z Holandii i osiem $z$ Flendrii zostaly namalowane przed $1400 \mathrm{r}$. 


\section{Inwentarz Franza Unterkirchera}

Tym razem inicjatywa podjęta została przez samą Bibliotekę Narodową - w latach 1957 i 1959 Franz Unterkircher opublikowal dwa tomy, które objęły wszystkie (razem przeszło pięć tysięcy) rękopisy iluminowane Austriaciej Biblioteki Narodowej, ułożone w kolejności sygnatur ${ }^{26}$. Każdemu rękopisowi (poza nielicznymi wyjątkami) poświęcone były cztery linijki tekstu: sygnatura, krótki tytul, język, ilość kart, materiał pisarski, wymiary, oraz notatka omawiająca ilość i charakter zdobnictwa, datowanie i lokalizację ${ }^{27}$. Dołączone tabele umożliwiaja wyszukiwanie informacji szczegółowej; jednakze nie dołączono ani ilustracji, ani informacji ikonograficznej. Pamiętajmy, że Unterkircher jako teolog $z$ wykształcenia, chętnie zestawial informacje, ale nie prowadzil samodzielnych badań w zakresie historii sztuki.

\section{Seria Ottona Pächta}

Urodzony w 1902 r. w Wiedniu Otto Pächt należal do grona czolowych przedstawicieli silnie ukierunkowanej metodologicznie „wiedeńskiej szkoły historii sztuki”. Po wyemigrowaniu do Anglii uwagę swą skupił na rękopisach iluminowanych. Oprócz wielu innych ważnych prac opublikował katalog rękopisów iluminowanych $w$ Bibliotece Bodleiańskiej w Oksfordzie (we współpracy $z$ Jonathanem J. G. Alexandrem) ${ }^{28}$. Pierwszy tom tego wydawnictwa, który $z$ pewnym opóźnieniem ukazał się w 1966 r., porządkuje materiały według lokalnych szkól, a wewnątrz tych podziałów chronologicznie. Notatki poświęcone poszczególnym rękopisom mają charakter skrótowego zestawienia; niemniej, często zawieraja wyniki wnikliwych fachowych analiz. Większość rękopisów jest reprezentowana przez przynajmniej jedną ilustrację.

Po powrocie do Wiednia w 1963 r. jego glównym zadaniem było wykładanie w Instytucie Historii Sztuki na Uniwersytecie Wiedeńskim. Mimo to podjąl się zadania przywrócenia do życia wiedeńskiej tradycji katalogowania rękopisów iluminowanych. Uczynil to poprzez zainicjowanie nowej serii wydawniczej: „Die illuminierten Handschriften und Inkunabeln der Österreichischen Nationalbibliothek" (lluminowane rękopisy i inkunabuły Austriackiej Biblioteki Narodowej). Patronat nad serią przejeła Austriacka Akademia Nauk (w miejsce Institut für Österreichische Geschichtsforschung), a instytucją wiodącą stał się Instytut His-

\footnotetext{
${ }^{26}$ Franz Unterkircher, Inventar der illuminierten Handschriften, Inkunabeln und Frühdrucke der Österreichischen Nationalbibliothek, t. 1-2, Wien 1957-1959. Tom pierwszy obejmuje rękopisy zachodnie, drugi - greckie, słowiańskie, hebrajskie, orientalne $\mathrm{i}$ inne, oraz iluminowane inkunabuły i starodruki. Pominięte zostały materiały iluminowane, które znajdują się w kolekcjach: papirusów, map, teatralnej oraz portretów, ponieważ nie ma w nich zabytków średniowiecznych.

${ }^{27}$ Jeżeli dany zabytek zostal zinwentaryzowany w ramach Beschreibende Verzeichnis, Unterkircher dodawał informację na ten temat, ale dalsze odnośniki są bardzo nieliczne, a dyskusja naukowa calkowicie wykluczona.

${ }^{28}$ Otto Pacht, J(onathan) J. G. Alexander, Illuminated Manuscripts in the Bodleian Library, Oxford, t. 1-3, Oxford 1966-1973. W przedmowie Pächt chwali wiedeńskie wydawnictwo Beschreibende Verzeichnis jako wzorcowe, podczas gdy sam musi się ograniczyć do skrótowego zestawienia.
} 
torii Sztuki Uniwersytetu Wiedeńskiego. W 1966 r., trzy lata po powrocie Pächta z emigracji, Akademia Nauk powołała do życia Komisję Wiedzy o Piśmie i Książce w Sredniowieczu (Kommission für Schrift- und Buchwesen des Mittelalters; por. przyp. 23). Tak stworzone zostały ramy instytucjonalne, w których Otto Pächt, na zaproszenie Herberta Hungera, mógł przystąpić do swego planu odnowienia wydawnictwa Beschreibendes Verzeichnis.

Przy wspólpracy swej asystentki Dagmar Thoss, Pảcht rozpoczął od katalogowania pozostalych rękopisów francuskich ${ }^{29}$. Hermann Julius Hermann ( $\uparrow$ 1953), kierownik projektu az do chwili, kiedy został zwolniony z pelnionej funkcji przez nazistów w 1938 r., po wojnie przekazał rękopis swej pracy obejmującej materiały francuskie Instytutowi Historii Sztuki (Kunsthistorische Institut). Czyniąc to Hermann zdawał sobie sprawę $z$ faktu, ze jego materiały odbiegają już od standardów wówczas obowiązujących, ale chcial, by jego wysilki posłużyły za punkt wyjściowy dla dalszych prac. Pächt wykorzystal otrzymane w spadku materiały, ale opracowal nowy schemat i wzorzec opisu ${ }^{30}$, który mial w założeniu być mniej wyczerpujący, ale skupiać się na pewnych naukowo klasyfikacjach. Dołączył więc punkt zatytułowany „Komentarz stylistyczny” (Stilistischer Kommentar) i zastosował porównawcze ilustracje w dowodzeniu analogii stylistycznych ${ }^{31}$. Ten aspekt opisu po dziś dzień pozostaje cechą charakterystyczną nowej serii wiedeńskiej. Kiedy porównamy układ dzisiaj wykorzystywanego schematu opisu $z$ przyjętym przez Pächta $w$ jego pierwszym tomie $z 1974$ r., od razu widać jak wiele zapożyczył on $z$ wcześniejszych tomów pod względem strukturalnym, oraz jak wielki krok naprzód uczynił w badaniach z dziedziny historii sztuki.

Pächt, oraz jego współpracownicy: Dagmar Thoss i Ulrike Jenni, opublikowali dwa tomy, które objęły resztę materiałów francuskich $(1974,1977)$, po czym rozpoczęli prace nad potężnym zasobem rękopisów niderlandzkich, pominiętych przez Hermanna (por. przyp. 25). W 1975 r. ukazał się tom poświęcony Holandii. Spośród czterech zaplanowanych na część flamandzka, pierwszy ukazał się w 1983 - prace nad nim nadzorowal Otto Păcht ( $†$ 1988); drugi opublikowany został w 1990 r. Dagmar Thoss nadal pracuje nad pozostałymi dwoma, które mają doprowadzić katalogowanie rękopisów zachodnioeuropejskich do szczęśliwego końca.

\footnotetext{
${ }^{29}$ Otto Pächt, Dagmar Thoss, Französische Schule I, Österreichische Akademie der Wissenschaften, Philosophisch historische Klasse, Denkschriften 118” = „Veröffentlichungen der Kommission für Schriftund Buchwesen", ed. Herbert Hunger, Reihe 1: Die illuminienten Handschriften und Inkunabeln der Österreichischen Nationalbibliothek 1, ed. Otto Păcht). Wien 1974.

${ }^{30}$ Co najbardziej rzuca sie w oczy, dostojny format in folio zostal zastapiony skromnym A4, a eleganckie tablice $z$ ilustracjami drukowane techniką kolotypii zwyczajnym offsetem. $Z$ drugiej jednak strony kolorowe ilustracje pokazują teraz najważniejsze elementy dekoracji, co jest poważnym usprawnieniem. Każdy $\mathrm{z}$ tomów dzieli się na dwie części: pierwszy zawiera katalog oraz ilustracje porównawcze, drugi zaś tablice $\mathrm{z}$ ilustracjami.

${ }^{31} \mathrm{Na}$ dodatek sprawdzano strukture składek oraz teksty, a wyniki tych dociekań byly włączane w opisy rękopisów.
} 
Autorem nowego dokonania w zakresie katalogowania rękopisów iluminowanych jest Dorothea Duda. Zaproponowała ona katalog rękopisów orientalnych najpierw Bibliotece Narodowej, a następnie Austriackiej Akademii Nauk. Herbert Hunger, przewodniczący Komisji Wiedzy o Piśmie i Książce, zaakceptowal propozycję uczonej, sugerując jednocześnie, by jej praca zostala włączona w serię redagowaną przez Ottona Pächta. Duda zmodyfikowała swe wstępne materiały w kierunku uzgodnienia schematu opisu $z$ wymaganiami serii ora $z$ przyjęła sugestie Hungera, by porządkować opisy według języków oryginalów. Wyniki jej prac ukazaly się w trzech tomach (perski, arabski i turecki), wydanych w latach 1983, 1992 i 2008 . Wewnątrz grup językowych kolejność opisów podąża według porządku sygnatur; ilustracje idą według kolejności chronologicznej. Dzięki inicjatywie Dorothei Dudy wypełniona została luka, często przeoczana w planach naukowych, a calościowy program skatalogowania wszystkich rękopisów uczynil kolejny krok ku ostatecznej realizacji.

\section{Seria Gerharda Schmidta}

Podobnie jak termin „Seria Ottona Pächta”, „Seria Gerharda Schmidta” jest również nazwą nieoficjalną. Schmidt objąl kierownictwo nad katalogowaniem rękopisów iluminowanych po śmierci Ottona Pächta. Pełnienie tej funkcji przychodziło mu tym łatwiej, gdyż tak jak jego poprzednik, byl jednocześnie profesorem Instytutu Historii Sztuki i czlonkiem Austriackiej Akademii Nauk. Schmidt $z$ jednej strony popieral wysiłki Dagmar Thoss, która kończyła prace nad materiałami flamandzkimi, $z$ drugiej zaś zainicjował ciagg zatytułowany „Szkoły środkowoeuropejskie” (Mitteleuropäische Schulen - MeSch), w celu zamknięcia ostatniego niezbadanego pola w zakresie katalogowania rękopisów iluminowanych Austriackiej Biblioteki Narodowej.

Podobnie jak miało to miejsce w 1911 r., gdy Paul Buberl wykazal konieczność zmian w schemacie opisu, młodsi współpracownicy, którzy przygotowali pierwszy tom podserii ${ }^{32}$, zgłosili nowe postulaty. Zwrócili uwage na wagę informacji kodykologicznych (np. wzór Chrousta przy badaniu składek) oraz dodatkowy danych co do treści. Wychodzili z założenia, że rękopis iluminowany powinien być rozpatrywany jako całościowe dzieło sztuki (Gesamtkunstwerk), w którym współgrają różnorodne czynniki kulturowe.

Stopniowe uszczegółowienie opisu wymaga klarownej struktury wykładu, $z$ rozróżnieniem informacji o charakterze kodykologicznym od charakterystyki pisma (pierwszy akapit opisu), oprawy, proweniencji i zawartości kodeksu ${ }^{33}$. Wszystkie te elementy stanowią jednak tylko wstęp, lub raczej podstawę, do cha-

${ }^{32}$ Andreas Fingernagel, Martin Roland, Mitteleuropäische Schulen I (ca. 1250-1350), „Österreichische Akademie der Wissenschaften, Philosophisch-historische Klasse, Denkschriften 245" = „Veroffentlichungen der Kommission für Schrift- und Buchwesen”, ed. Otto Kresten, Reihe 1: Die illuminierten Handschriften und Inkunabeln der Österreichischen Nationalbibliothek 10, ed. Gerhard Schmidt), Wien 1997.

${ }^{33}$ Co się tyczy rękopisów niemieckich dodany został specjalny akapit poświęcony problemom językowym. 
rakterystyki z dziedziny historii sztuki oraz klasyfikacji, które są przedstawione w drugiej kolejności. Naglówek „Zdobnictwo” (Buchschmuck) rozpoczyna sekcję opisu o charakterze narracyjnym. Poczynając od najmniejszych elementów, jak np. rubrykacja, po kolei wymieniane są wszystkie kategorie dekoracji. Pierwszy akapit tej części zamyka podsumowanie ilościowe bogatego zdobnictwa, opisanego poniżej w sposób bardziej szczegółowy ${ }^{34}$. W większości wypadków do opisu różnych typów zdobnictwa, np. prostych inicjałów wykonanych piórkiem, inicjałów filigranowych, inicjałów malowanych farbami kryjącymi $z$ banderolami lub bez, inicjałów ze scenami figuralnymi, miniatur, bordiur oraz niezależnych elementów takich jak szkice, wykorzystywany jest zintegrowany wzorzec opisu. Jedynie $\mathrm{w}$ przypadkach ważnych $z$ punktu widzenia ikonografii elementów przedstawień figuralnych obiekty omawiane są kolejno jeden po drugim.

Ta część opisu, która w serii Ottona Pächta nosiła miano „Komentarz stylistyczny”, obecnie jest zatytulowana „Styl i klasyfikacja” (Stil und Einordnung). Zmiana miała na celu podkreślenie integralność obiektu i informacji, które zgromadzone zostały na podstawie wszystkich odnośnych dziedzin wiedzy, bez względu na to, czy przynależnych do domeny historii sztuki, czy też nie. Nie jest to żadna nowość w katalogowaniu rękopisów, ale zespołowi wydało się, że należy podkreślić interdyscyplinarność wykonywanej pracy. Każdy opis kończy się, tak jak bylo to dawniej, wybraną bibliografia.

Jednak zmianom uległ nie tylko schemat opisu; także metoda pozyskiwania podstaw materiałowych wymagała nowego podejścia, ponieważ w trakcie przygotowywania MeSch I okazalo się, że inwentarz Unterkirchera (por. przyp. 26) jest zawodny - niektóre elementy zdobnicze (zwłaszcza te, które powstały przy pomocy piórka) zostały niemal calkowicie pominięte. Około roku 2000 wyloniony został podzespół, którego zadaniem było przejrzenie wszystkich rękopisów $z$ zasobu Biblioteki Narodowej, aby odtąd podstawy tworzenia kolejnych tomów MeSch II były całkowicie pewne.

Decyzja o przeglądzie całości materiałów była niebagatelna - w Bibliotece stale przybywa (i to w poważnych ilościach) obiektów późnośredniowiecznych, lokalnego pochodzenia austriackiego, o niskiej na ogół wartości artystycznej, które jednak zasługują na uwzględnienie. Niemniej jednak badania $z$ ostatnich lat wykazały, że ustalanie pochodzenia materialów $\mathrm{i}$ ich datowanie na podstawie analizy zdobnictwa filigranowego (niem.: Fleuronnée) jest możliwe, co otworzyło nowe, szerokie pole dla dalszych badań.

Dla tych ilościowo potężnych nowych materiałów, które $\mathrm{z}$ punktu widzenia historyka sztuki nie przedstawiają szczególnej wartości, trzeba było opracować odrębny skrócony schemat opisu. Mimo skondensowania informacji nie zrezygnowano jednak $z$ materiałów ilustracyjnych - każdy opis ma dołączoną fotografię. W planowanych tomach wprowadzona została nowa subkategoria, „Wykaz rękopisów pominiętych” (Liste der nicht beschriebenen Handschriften),

\footnotetext{
${ }^{34}$ Podsumowanie tego rodzaju Hermann Julius Hermann wprowadził już w pierwszym swym tomie (1905; por. s. 6); od MeSch II spotyka się je w każdym kolejnym woluminie serii.
} 
aby czytelnicy mieli pewność, że dany obiekt został celowo wykluczony, a nie przypadkowo pominięty.

Wraz przeniesieniem się Instytutu Historii Sztuki w 1997 r. na nowy kampus Uniwersytetu Wiedeńskiego zespól stworzony przez Gerharda Schmidta w końcu uzyskal warunki lokalowe, które tak bardzo były mu potrzebne. Zespół Schmidta oraz naukowy legat zapisany Uniwersytetowi przez Ottona Pảchta (biblioteka podręczna wyspecjalizowana $\mathrm{w}$ tematyce rękopisów iluminowanych, jego korespondencja naukowa oraz rękopisy) razem złożyły się na nową komórkę Instytutu - Archiwum Ottona Pächta (Pächt Archiv, Bibliotheksstiftung Otto Pächt).

Pierwszy tom serii MeSch objął stulecie 1250-1350; pod względem geograficznym zgromadzone zostały materiały pochodzące $z$ wszystkich regionów Europy Środkowej. Niezwykle bogate zasoby rodem z Czech, wraz z rękopisami morawskimi, śląskimi i węgierskimi, powstałe po 1350 r., zostały wyodrębnione, a pierwszy tom tej podserii został wydany w 2004 r. przez Ulrike Jenni, Marię Theisen i Karela Stejskala.

Schemat opisu wypracowany przez Ottona Pảchta okazal się równie przydatny, jak ten rodem $z$ pierwszej serii; dodatkowo okazalo się, że obydwa wywarły równie wielki wpływ na podejście metodologiczne innych środowisk. W rozpropagowaniu doświadczeń austriackich wielką rolę odegrały: Elisabeth Klemm, uczennica Ottona Păchta w Wiedniu, która swymi monachijskimi tomami ${ }^{35}$ zainicjowała katalogowanie rękopisów iluminowanych w Niemczech, oraz François Avril, której seria paryska ${ }^{36}$ odegrała podobną rolę we Francji.

\section{Stan obecny}

Główna część projektu "Mitteleuropäische Schulen" (MeSch), prowadzonego przez Gerharda Schmidta, zajmuje się rękopisami środkowoeuropejskimi z Österreichische Nationalbibliothek. Przygotowywany obecnie do wydania tom piąty, praca zbiorowa koordynowana przez Susanne Rischpler i Martina Rolanda, obejmuje materiały $z$ Wiednia i Dolnej Austrii datowane od 1410 do $1450^{37}$.

\footnotetext{
${ }^{35}$ Elisabeth Klemm, Die romanischen Handschriften der Bayerischen Staatsbibliothek 1: Die Bistümer Regensburg, Passau und Salzburg, „Katalog der illuminierten Handschriften der Bayerischen Staatsbibliothek in München", 3/1, Wiesbaden 1980. Ukazaly się już kolejne tomy tej serii. E. Klemm podkreśla w przedmowie rolę odegraną w przedsięwzięciu przez jej mistrza.

${ }^{36}$ Manucrits enluminés d'origine italienne 1: François Avril, Yolanta Zaluska, Vle-XIle siècles, Paris 1980. W latach późniejszych ukazały się dalsze tomy. W przedmowie autorzy wymieniają katalogi Hermanna oraz Pächta jako wzór. który naśladowali, chociaż jak zaznacza Avril, jego intencją było znalezienie złotego środka między szczegółowymi opisami wiedeńskimi a lakonicznością oksfordzkich.

${ }^{37}$ Mitteleuropäische Schulen V (ca. 1410-1450) Wien und Niederösterreich, Bearbeitet von Christine Beier, Andreas Fingernagel, Katharina Hranitzky, Veronika Pirker-Aurenhammer, Susanne Rischpler, Martin Roland, Michaela Schuller-Jukes; unter Mitarbeit von Margit Elsigan, Martin Haltrich, Alois Haidinger, Anna Reisenbichler und Maria Stieglecker. „Österreichische Akademie der Wissenschaften, Philosophisch-historische Klasse, Denkschriften” $=$ „Veröffentlichungen der Kommission für Schrift- und Buchwesen", ed. Otto Kresten, Reihe 1: Die illuminierten Handschriften und Inkunabeln der Österreichischen Nationalbibliothek 14, ed. Gerhard Schmidt.
} 
Tom szósty (MeSch VI), który zawiera opisy pozostałych rękopisów austriackich, niemieckich oraz szwajcarskich $z$ tego okresu, praktycznie jest już gotów; do zakończenia całości pozostały tylko prace redakcyjne.

Specyfika finansowania głównego projektu wymusza na zespole regularne poszukiwanie nowych pracowników i kolegów, ci zaś, którzy już wyszkolili się w skomplikowanej naturze katalogowania, muszą rozglądać się za innymi zadaniami. I tak Andreas Fingernagel jest obecnie dyrektorem Oddziału Rękopisów Austriackiej Biblioteki Narodowej, Friedrich Simader jest kuratorem w tejże instytucji. Veronika Pirker-Aurenhammer pracuje jako kurator kolekcji średniowiecznej w Österreichische Galerie im Belvedere, a Karl-Georg Pfändtner pracuje w Bawarskiej Bibliotece Krajowej w Monachium. Dwie koleżanki pozostały wierne katalogowaniu rękopisów iluminowanych: Christine Beier zapoczątkowała serię opracowującą materiały w Bibliotece Uniwersyteckiej w Grazu, Katharina Hranitzky zaś zajmuje się zbiorami Oberösterreichische Landesbibliothek w Linzu. Powyższe przykłady karier zawodowych pokazują jak ważną rolę w życiu zawodowym odgrywa doświadczenie zdobyte w Archiwum Ottona Pächta.

Równolegle $z$ pracami wydawniczymi badania bibliologiczne otwierają nowe wyzwania i możliwości naukowe: znaki wodne i inkunabuly.

Dzięki współpracy z Aloisem Haidingerem i Marią Stieglecker, członkami Komisji Paleograficznej i Kodykologicznej (por. przyp. 23), nasze traktowanie filigranów osiągnie najwyższy poziom światowy. Jednocześnie powstaje zintegrowana baza danych (http://www.ksbm.oeaw.ac.at/wz/wzma.php), co w efekcie ma przynieść - przywołując terminologię ekonomiczną - sytuację typu „win-win”, raz jeszcze podkreślając wiodącą pozycję wiedeńskich projektów badawczych na obydwu tych polach.

Pierwsze książki wydrukowane za pomocą ruchomych czcionek, techniki opracowanej przez Johannesa Gutenberga w Moguncji, ukazaly się po $1450 \mathrm{r}$. Wzorowane na rękopisach, inkunabuły często były zdobione iluminacjami. Ponieważ zestawienia inkunabułów $z$ czasów Hermanna i Unterkirchera nie były nam dostępne - a na dodatek najprawdopodobniej nie spelniałyby juz dzisiejszych wymagań - trzeba było dokonać przeglądu całego zasobu inkunabulów, by wykryć wszystkie przykłady iluminacji. Zadanie to przypadło Armandowi Tifowi; ukończenie prac przewidywane jest na $2010 \mathrm{r}$.

Zwornikiem prac katalogowych nad środkowoeuropejskimi rękopisami iluminowanymi $z$ drugiej połowy XV wieku jest powstająca ważna baza danych (zawierająca informacje na temat 3500 zabytków). Wprowadzaniem danych do bazy zajmuje się Regina Cerman, która przegląda kodeksy i uzupełnia dokumentacje fotograficzną. Obecnie baza zawiera już około 60000 fotografii cyfrowych. Wszystkie dokumentują rękopisy i inkunabuły Austriackiej Biblioteki Narodowej ${ }^{3 \mathrm{~s}}$.

\footnotetext{
${ }^{38}$ Zbiory tradycyjnych i cyfrowych fotografii, należących do innych bibliotek (ok. 25000 podobizn) nie zostały uwzględnione w tej liczbie.
} 
Kierownikiem podsekcji czeskiej jest Maria Theisen; współpracuje $z$ nią Ulrike Jenni, która co prawda przeszła na emeryturę w roku 200?, ale nadal jest czynna naukowo. Innym przykładem emerytowanego pracownika, który wciąż jest aktywny, jest Dagmar Thoss, katalogująca rękopisy flamandzkie (por. s. 14).

Jak już wspomniano wcześniej, Archiwum Ottona Pächta włączyło w zakres swych zainteresowań nowe zbiory, przechowywane poza Wiedniem. Projekt poświęcony kolekcjom $z$ Grazu wystartował dzięki inicjatywie Michaela-Victora Schwarza, profesora historii sztuki $z$ Wiednia. Prace wykonuje Christine Beier, która opiekuje się rękopisami XIV- i XV-wiecznymi. Profesor Schwarz obecnie recenzuje oprogramowanie, które miałoby posłuzyć do katalogu rękopisów XIII-wiecznych. Zadania tego chcą się podjąć Michaela Schuller-Jukes (w chwili obecnej zatrudniona przy projekcie w Linzu) oraz Anna Reisenbichler (pełniąca odpowiedzialne funkcje przy głównym projekcie wiedeńskim).

Katharina Hranitzky, uprzednio członek zespołu głównego, przygotowała i przeprowadzila podobny projekt w Linzu. Niedawno otrzymała dalsze fundusze na kontynuowanie rozpoczętego katalogowania.

Oprócz przygotowywania drukowanych katalogów według wiedeńskiego wzorca, głównego celu wszystkich dotychczas wymienionych działań, ważne jest także testowanie nowych metod przedstawiania materialów przez pracowników Archiwum Ottona Pächta. Maria Theisen odpowiada za naszą stronę internetową (http://paecht-archiv.univie.ac.at), na której znajdują się informacje dotyczące archiwum, zespołu, zasobów oraz nieco dodatkowych materiałów naukowych ${ }^{39}$. Wstępnym projektem internetowym była baza danych zaprojektowana w glównej mierze przez Friedricha Simadera oraz inwentaryzacja romańskich rękopisów w zbiorach austriackich ${ }^{40}$, przygotowana w ramach przedsięwzięcia nadzorowanego przez Martinę Pippal z Instytutu Historii Sztuki na Uniwersytecie Wiedeńskim.

Nowy wzorzec indeksowania sieciowego został przetestowany w ramach krótkiego inwentarza wszystkich rękopisów i inkunabułów kanoników regularnych reguły św. Augustyna $z$ Herzogenburga w Dolnej Austrii. Po przejrzeniu tego względnie niewielkiego zbioru wykonano przeszlo 1500 ilustracji cyfrowych. Chociaż Armand Tif i Martin Roland przedstawili rezultaty swych indywidualnych prac niezależnie w Internecie ${ }^{41}$, to jednak od samego początku planowania przewodnią ideą było połączenie tego inwentarza $z$ bazą danych, nad przygotowaniem której pracuje Alois Haidinger $z$ Komisji Wiedzy o Książce i Piśmie (por. s. 13), w której mają zostać zebrane informacje na temat wszystkich rękopisów przechowywanych w Austrii ${ }^{42}$. Jeżeli użytkownicy pozytywnie zaopiniują schemat zastosowany po raz pierwszy w Herzogenburgu, wówczas inne, mało znane

${ }^{39} \mathrm{http}: / /$ paecht-archiv.univie.ac.at/dateien/links.html

${ }^{40} \mathrm{http} / /$ /homepage.univie.ac.at/Martina.Pippal/hssdata.htm.

${ }^{41} \mathrm{http}: / /$ paecht-archiv.univie.ac.at/ki/hzbg/hzbg_hss_webbilder/index_hzbg_startseite.html. Strona aktywna od maja 2009.

${ }^{42}$ http://www.ksbm.oeaw.ac.at/_scripts/php/manuscripts.php. 
kolekcje o podobnej liczebności (jak w Stams w Tyrolu), zostaną włączone do przedsięwzięcia.

Chociaż żaden $z$ pracowników Archiwum Ottona Pảchta nie uważa się za autorytet międzynarodowy (podobnie jak instytucję, w której pracuje), porównanie parametrów poucza, że prawda jest inna. Personel liczący przeszło dziesięć osób - wyspecjalizowanych badaczy, publikowanie katalogów w równomiernych odcinkach czasowych, wysoce wyspecjalizowana biblioteka, potężna kolekcja ilustracji dla celów porównawczych oraz stale pojawiające się nowe pomysty to cechy, którym trudno dorównać.

Przełożył Jacek Soszyński 